\title{
GC-MS/MS method for simultaneous determination of ester forms of 3-MCPD and 2-MCPD in infant formula
}

\author{
Le Dinh Chi ${ }^{1}$, Nguyen Nhu Thuong1,2 ${ }^{1,}$ Vu Ngoc Tu${ }^{2}$, Le Thi Hong Hao ${ }^{2}$, Tran Cao Son ${ }^{2 *}$ \\ ${ }^{1}$ Hanoi University of Pharmacy, Hanoi \\ ${ }^{2}$ National Institute for Food Control, Hanoi
}

(Received: 08/04/2020; Accepted: 10/06/2020)

\section{Abstract}

A sensitive GC-MS/MS method has been developed and validated for determining ester forms of 3-MCPD and 2-MCPD in infant formula, using 3-MCPD-d5 and 2-MCPD-d5 as internal standards, respectively. The esters of MCPDs were extracted from infant formula powder with mixture of ethanol/n-hexane/diethyl ether $(1 / 1 / 1, v / v / v)$, then treated with sulfuric acid to release free MCPDs. Free MCPDs and internal standards were derivatized with phenylboronic acid and the corresponding derivatives were used for GC-MS/MS analysis. The chromatographic separation was performed in a DB-5MS capillary column using helium as mobile phase at flow rate of $1 \mathrm{~mL} / \mathrm{min}$. Tandem mass spectroscopic detection of each analyte was done in MRM mode by monitoring one precursor ion and two product ions. Validation results confirmed the suitability of the developed method for intended application. Application of the method in samples collected from different provinces in Vietnam detected esterified 3-MCPD in 38.9\% of samples, esterified 2-MCPD in $34.7 \%$ of samples.

Keyword: esters, 3-MCPD, 2-MCPD, GC-MS/MS, infant formula.

\section{INTRODUCTION}

The esters of monochloropropanediol (MCPD), particularly those of 3-monochloropropane-1,2-diol (3-MCPD) and of 2-monochloropropane-1,3-diol (2-MCPD), are detected in a wide range of retail outlet and home-made foods and food ingredients, mostly from oil content $[1,3]$. These contaminants were found in foods either under free forms or, even in much larger amounts, esterified forms, mostly with long chain $\left(\mathrm{C}_{14}-\mathrm{C}_{18}\right)$ fatty acid [4-5]. The fat in infant formula, which contains refined vegetable oil, is the main source of glycidol, 2-MCPD and 3-MCPD [1]. Among the MCPDs, 3-MCPD is the most dangerous substance, with well-established immunotoxicity [6], carcinogenicity [7] and infertility [8]. The toxic effects of MCPDs were caused by free MCPDs, especially 3-MCPD. However, fatty acid esters of 3-MCPD and other MCPDs can release free MCPDs after hydrolysis by enzyme such as lipase [9]. Therefore, the human exposure to fatty acid esters of MCPDs could also be potentially dangerous [10]. Due to its toxicity, European Scientific Committee on Food has proposed the tolerable daily intake (TDI) for 3-MCPD as $2 \mathrm{mg} / \mathrm{kg}$ of body weight [11].

Currently, the determination of fatty acid esters of MCPDs can be performed directly or indirectly through the corresponding free MCPDs after hydrolysis. The direct determination has been tried using LC-MS [12], but this approach was hindered by the variety of fatty acids forming esters with MCPDs as well as by the lack of certified reference material for each particular ester of MCPDs. Therefore, the most feasible approach is still the estimation of total fatty acid esters

${ }^{*}$ Corresponding author: Tel: 0988683282 Email: sontc@nifc.gov.vn 
of MCPDs through the assay of free MCPDs released after hydrolysis. Different methods using LC-MS, GC-MS have been developed for determination of free MCPDs in food [13]. And because MCPDs in food is considered as a serious health issue, AOAC International has also provided a Standard Method Performance Requirements (SPMR) for any analytical method to be used for determination of 2-MCPD, 3-MCPD, esters of 2- and 3-MCPD as well as glycidyl esters in nutritional formula [14]. AOAC International has adopted the GC-MS method for the determination of 2-MCPD, 3-MCPD and glycidyl esters (GE) in nutritional formula [15]. This method, however, monitors only one ion for each analyte, which may affect the method specificity in some complex matrices. In this study, a method using GC-MS/MS was developed and validated for the determination of fatty acid esters of 2-MCPD and 3-MCPD in infant formula.

\section{MATERIALS AND METHODS}

\subsection{Chemicals and reagents}

Phenyl boronic acid was purchased from Toronto Research Chemicals (North York, ON, Canada), potassium oxalate, sodium sulfate, sodium hydrogen carbonate, ammonium sulfate, sulfuric acid, methanol, diethyl ether, n-hexane, ethyl acetate, tetrahydrofurane, and isooctane were purchased from Merck Vietnam (Hanoi, Vietnam). All reagents, chemicals and solvents were analytical grade. Ultra-pure water was used for preparation of all aqueous solutions. Solid phase extraction columns Bond Elut $\mathrm{NH}_{2}$ (amino) and Bond Elut SI (silica) were obtained from Agilent (Santa Clara, CA, USA).

The methanolic solution of sulfuric acid used for hydrolysis of esters of MCPDs was prepared by adding $1.8 \mathrm{~mL}$ of concentrated sulfuric acid to $50 \mathrm{~mL}$ of methanol then diluted with methanol to make $100 \mathrm{~mL}$. The saturated solution of sodium hydrogen carbonate was prepared by mixing $4.8 \mathrm{~g}$ of sodium hydrogen carbonate with $50 \mathrm{~mL}$ of water. The ammonium sulfate solution was prepared by dissolving $20 \mathrm{~g}$ of ammonium sulfate in $50 \mathrm{~mL}$ of water. The phenylboronic acid (PBA) solution for derivatization of 3-MCPD and 2-MCPD was prepared by dissolved $0.4 \mathrm{~g}$ of PBA in $10 \mathrm{~mL}$ of diethyl ether.

\subsection{Preparation of standard solutions}

The reference standards 3-MCPD, 2-MCPD, 3-MCPD-d5, 2-MCPD-d5, 3-MCPD-1,2bis-palmitoyl (PP-3-MCPD), 3-MCPD-d5-1,2-bis-palmitoyl (PP-3-MCPD-d5), 2-MCPD-1,3bis-palmitoyl (PP-2-MCPD-d5) were purchased from Toronto Research Chemicals (North York, ON, Canada), while 2-MCPD-1,3-bis-palmitoyl (PP-2-MCPD) was purchased from Larodan AB (Solna, Sweden).

Stock standard solutions of 2-MCPD and 3-MCPD and stock IS solutions of 2-MCPD-d5 and 3-MCPD-d5 were prepared at $0.01 \mathrm{mg} / \mathrm{mL}$ in $n$-hexane/ethyl acetate $(85 / 15, \mathrm{v} / \mathrm{v})$. The mix standard solutions were prepared by exact dilution of stock standard solutions and stock IS solutions in n-hexane/ethyl acetate $(85 / 15, \mathrm{v} / \mathrm{v})$ to obtain desired concentration of 2-MCPD and 3-MCPD, and concentration of ISs (2-MCPD-d5 and 3-MCPD-d5) was maintained at 500 $\mathrm{ng} / \mathrm{mL}$. To establish the standard curve, at each concentration of 2-MCPD and 3-MCPD, 0.25 $\mathrm{mL}$ of mix standard solution was evaporated to dryness by a nitrogen flow, then the residue was dissolved in $2 \mathrm{~mL}$ of ethyl acetate and gathered in a stoppered tube for derivatization of MCPDs and ISs (see 2.5 for details of derivatization step). 


\subsection{Preparation of sample solution}

\subsubsection{Samples}

The samples of infant formula were collected randomly at the markets and commercial center in 2 cities (Hanoi, Hai Phong) and 2 provinces (Thai Nguyen, Thua Thien Hue) to be used in method development, validation and application. In which samples did not contain 3-MCPD and 2-MCPD under esterified forms have been used as matrix for spiked samples in method development and validation.

\subsubsection{Internal standards for sample solution}

The PP-3-MCPD-d5 and PP-2-MCPD-d5 were dissolved in toluene to obtain a solution containing the concentrations of PP-3-MCPD-d5 and of PP-2-MCPD-d5 equivalent to 500 $\mathrm{ng} / \mathrm{mL}$ of free 3-MCPD-d5 and $500 \mathrm{ng} / \mathrm{mL}$ of free 2-MCPD-d5, respectively.

\subsubsection{Sample pretreatment}

Referencin $g$ from published results of other works $[13,15]$ and preliminary experiments, the procedure for extracting fatty acid esters of MCPDs from infant formula was developed as followed: About $1.0 \mathrm{~g}$ of homogenized sample, accurately weighed, was dissolved in $15 \mathrm{~mL}$ of distilled water and transferred into a $100 \mathrm{~mL}$ separation funnel. Before extracting the aqueous liquid with organic solvent, $0.25 \mathrm{~mL}$ of solution A was added into the separation funnel, and the funnel was gently shaken in 10 second to mix. Two milliliters of saturated solution of potassium oxalate were added into the separation funnel, and the aqueous layer was extracted 2 times, each time with $60 \mathrm{~mL}$ of mixture of ethanol/n-hexane/diethyl ether $(1 / 1 / 1, \mathrm{v} / \mathrm{v} / \mathrm{v})$ by shaking in 3 minutes. The aqueous layer was then discarded, the organic extract was collected and rinsed with $5 \mathrm{~mL}$ of water. The water was discarded after rinsing, and the organic layer was filtered through a funnel containing anhydrous sodium sulfate, the filtrate was evaporated to dryness in a rotator vacuum evaporator at $40^{\circ} \mathrm{C}$. The residue was dissolved with $2 \mathrm{ml}$ of $\mathrm{n}$-hexane. The reconstituted liquid went through a Bond Elut $\mathrm{NH}_{2}$ column previously activated with $2 \mathrm{~mL}$ of $\mathrm{n}$-hexane/ethyl acetate $(85 / 15, \mathrm{v} / \mathrm{v})$. The esterified MCPDs and esterified ISs were then eluded from Bond Elut $\mathrm{NH}_{2}$ column with $10 \mathrm{~mL}$ of $n$-hexane/ethyl acetate $(85 / 15, \mathrm{v} / \mathrm{v})$ at speed of $1-2 \mathrm{~mL} / \mathrm{min}$. The elution aliquot was evaporated to dryness by a nitrogen flow, the residue was dissolved with 1 $\mathrm{mL}$ of tetrahydrofurane for acid hydrolysis to release free MCPDs and free ISs.

\subsubsection{Acid hydrolysis of esterified 2-MCPD, 3-MCPD and esterified ISs}

The acid hydrolysis of esterified 3-MCPD, esterified 2-MCPD in sample and that of PP3-MCPD-d5 (IS) and PP-2-MCPD-d5 (IS) were carried out based on results of previous works [16-19] with some adjustments after preliminary study. The liquid obtained in 2.4.2 was mixed with $1 \mathrm{~mL}$ of methanolic solution of sulfuric acid in a tightly sealed tube, shaken vigorously in $30 \mathrm{~s}$ and incubated at $40^{\circ} \mathrm{C}$ in 16 hours. The reaction was stopped by adding $0.5 \mathrm{~mL}$ of saturated solution of sodium hydrogen carbonate. The liquid in the tube was evaporated to dryness by a nitrogen flow, the residue was reconstituted in $1 \mathrm{~mL}$ of solution of ammonium sulfate. The free fatty acids released after hydrolysis and other fatty matters were eliminated by extracting 2 times, each time with $1 \mathrm{~mL}$ of $\mathrm{n}$-hexane, then the $\mathrm{n}$-hexane layer was discarded. The ammonium sulfate layer was extracted 2 times, each time with $1 \mathrm{~mL}$ of ethyl acetate to collect the free MCPDs and free ISs. The organic layer was gathered in a centrifuge tube containing $20 \mathrm{mg}$ of granular anhydrous sodium sulfate to eliminate any trace of water. The tube was shaken gently 
in 5 seconds, then centrifuged at $1.000 \mathrm{rpm}$ in 3 minutes. The anhydrous organic extract was then transferred to a stopper tube.

\subsubsection{Derivatization of MCPDs and ISs with phenylboronic acid}

The whole liquid in ethyl acetate of sample solutions (as obtained in 2.4.3) and standard solutions (as obtained in 2.3) was mixed with $150 \mathrm{~mL}$ of PBA solution, vortexed in 30 seconds then shaken in ultrasonic bath in 5 minutes for derivatization. The liquid inside the stoppered tube was evaporated under a nitrogen flow, the residue was re-dissolved in $0.25 \mathrm{~mL}$ of isooctane. The obtained solution was injected into GC-MS/MS system. Sample solution would contain each free IS (3-MCPD-d5 and 2-MCPD-d5) at concentration about $500 \mathrm{ng} / \mathrm{mL}$ after acid hydrolysis.

\subsection{Instrument conditions}

\subsubsection{Gas chromatography conditions}

The gas chromatography apparatus GC 7.890 connected to MS 7.000 B mass spectrometer of Agilent (Santa Clara, CA, USA) was used for method development and validation. Mass Hunter software (version B.05.02.1032) of Agilent (Santa Clara, CA, USA) was used for data processing and evaluation.

The gas chromatographic analysis was performed in a DB5-MS column (length: $30 \mathrm{~m}$, inner diameter: $0.25 \mathrm{~mm}$, thickness of stationary film layer: $25 \mathrm{~mm}$ ) of Phenomenex (Torrance, CA, USA) with helium (purity: $99.99 \%$ ) as mobile phase maintained at $1.0 \mathrm{~mL}$ per minute. The sample injection volume was $1.0 \mathrm{~mL}$ in splitless mode. Injector temperature was maintained at $280^{\circ} \mathrm{C}$. Column temperature was controlled by a program as followed: the initial hold at $60^{\circ} \mathrm{C}$ was maintained in 1 minute, then temperature was ramped to $150^{\circ} \mathrm{C}$ at speed of $6^{\circ} \mathrm{C}$ per minute and hold at $150^{\circ} \mathrm{C}$ was maintained in 2 minutes, then temperature was increased to $270^{\circ} \mathrm{C}$ at speed of $40^{\circ} \mathrm{C}$ per minute and hold at $270^{\circ} \mathrm{C}$ in 5 minutes.

\subsubsection{MS/MS conditions}

The EI ion source was set at positive mode, with ionization energy at $70 \mathrm{eV}$. The transfer line from gas chromatography apparatus to $\mathrm{MS}$ spectrometer was maintained at $270^{\circ} \mathrm{C}$, the temperature of EI ion source and triple quadrupoles was maintained at $250^{\circ} \mathrm{C}$ and $150^{\circ} \mathrm{C}$, respectively. The precursor and product ions of derivatives with PBA of 3-MCPD (PBA-3MCPD), of 2-MCPD (PBA-2-MCPD), of 3-MCPD-d5 (PBA-3-MCPD-d5), and of 2-MCPD-d5 (PBA-2-MCPD-d5) were recorded in multi-reaction monitoring (MRM) mode. To select precursor ion, mass spectra of each derivative was recorded in full scan mode with $\mathrm{m} / \mathrm{z}$ from 130 to 220 in order to find ion with most sensitive and reproducible abundance to be used as precursor ion in MRM mode. All product ions issued from the chosen precursor ion were then recorded in product ion mode to find out 2 product ions, one would be used to quantitative analysis of each derivative, the other would be used for identification purpose (see Figure 1). For identification purpose, precursor ion $\mathrm{m} / \mathrm{z} 147$ and two product ions m/z 91 and m/z 105 were monitored for PBA-3-MCPD, precursor ion m/z 196 and two product ions m/z 91 and m/z 104 were monitored for PBA-2-MCPD. The quantitative analysis of 3-MCPD was performed with the ratio between abundance of product ion $\mathrm{m} / \mathrm{z} 91$ of PBA-3-MCPD and that of product ion $\mathrm{m} / \mathrm{z} 93$ issued from precursor ion $\mathrm{m} / \mathrm{z} 150$ of PBA-3-MCPD-d5. The quantitative analysis of 2-MCPD was performed with the ratio between abundance of product ion m/z 104 of PBA-2-MCPD 
and that of product ion m/z 107 issued from precursor ion m/z 201 of PBA-2-MCPD-d5. For the formation of product ions, the collision energy was set for each ion as presented in Table 1.

Table 1. Collision energy for product ion formation

\begin{tabular}{lccc}
\hline Analyte & Precursor ion $(\mathbf{m} / z)$ & Product ion $(\mathbf{m} / z)$ & Collision energy $(\boldsymbol{e V})$ \\
\hline $3-M C P D$ & 147 & $91^{*}$ & 24 \\
& 147 & 105 & 26 \\
$2-M C P D$ & 196 & $104^{*}$ & 24 \\
$3-M C P D-d 5$ & 196 & 91 & 26 \\
& 150 & $93^{*}$ & 22 \\
$2-M C P D-d 5$ & 150 & 107 & 20 \\
& 201 & $107^{*}$ & 18 \\
& 201 & 93 & 22 \\
\hline
\end{tabular}

* Quantitative ion

\subsection{Method validation}

\subsubsection{Specificity}

Specificity evaluation was done by injecting separately solution of standard, sample spiked with PP-3-MCPD and PP-2-MCPD, sample spiked with free 3-MCPD and 2-MCPD, and blank infant formula sample.

\subsubsection{Linearity}

To evaluate the linearity of the method, mixed standard solutions containing 3-MCPD, 2-MCPD as well as ISs were prepared by diluting stock standard solution with mobile phase to obtain different exact concentrations of 3-MCPD and 2-MCPD (100, 250, 500, 1.000, 2.500 $\mathrm{ng} / \mathrm{mL}$ ), and of each IS (3-MCPD-d5 and 2-MCPD-d5) fixed at $500 \mathrm{ng} / \mathrm{mL}$. Three injections from each concentration were analyzed under the same conditions. The linear regression analysis was used to evaluate the linearity of the calibration curve.

\subsection{3. $L O D$ and $L O Q$}

The limit of detection (LOD) and limit of quantitation (LOQ) of 3-MCPD and 2-MCPD were determined by analyzing different solutions of 3-MCPD and 2-MCPD and measuring the signal-to-noise ratio obtained with abundance of quantitative product ion for each analyte. The limit of detection (LOD) is the concentration giving a signal-to-noise ratio about $3: 1$, and the limit of quantitation (LOQ) is the concentration giving a signal-to-noise ratio about $10: 1$ with RSD of peak response fell within the accepted range and the LOQ met the AOAC SPMR [14].

\subsubsection{Accuracy}

The accuracy of the method was determined by recovery studies for 3-MCPD and 2-MCPD from blank matrix and comparing to AOAC International SPMR [20]. Exact amounts of PP-3-MCPD and PP-2-MCPD were mixed with blank matrix in such a way that the spiked samples, after preparation process, yielded solutions containing 3-MCPD and 2-MCPD at three 
concentration levels about 100, 500 and $2.000 \mathrm{ng} / \mathrm{mL}$ The percentage recovery of added 3-MCPD and 2-MCPD and the RSD were calculated for each replicate samples.

\subsubsection{Precision}

The method precision including repeatability and intermediate precision were determined by six measurements of infant formula samples spiked with PP-3-MCPD and PP-2-MCPD at three concentration levels as per 2.5.4. on same day and on two different days, respectively.

\section{RESULTS AND DISCUSSION}

\subsection{Method development and optimization}

The method development step was performed to select conditions of sample treatment (solvent for ester extraction, conditions of cleansing), conditions for GC separation (derivatizing agent, type of stationary phase, mobile phase, temperature program) and those of mass detection conditions (working conditions of ion source, collision cell, $\mathrm{m} / \mathrm{z}$ of precursor ion ( $\mathrm{s}$ ), of product ion(s)). For this purpose, preliminary trials to develop the final GC-MS/MS method were performed by varying conditions of sample treatment, GC separation and tandem mass detection. The results of preliminary optimization were summarized in Table 2 and the mass spectral of the precursor ions of the analytes was shown in Figure 1.

Table 2. Results of preliminary optimization

\begin{tabular}{|c|c|c|c|c|c|}
\hline \multicolumn{6}{|c|}{ Conditions for sample treatment } \\
\hline $\begin{array}{l}\text { Solvent used } \\
\text { to disperse } \\
\text { sample }\end{array}$ & $\begin{array}{c}\text { Solvent used to } \\
\text { extract esterified } \\
\text { MCPDs }\end{array}$ & $\begin{array}{l}\text { Cleansing step by } \\
\text { dissolving in a } \\
\text { second solvent }\end{array}$ & $\begin{array}{l}\text { Cleansing } \\
\text { step by SPE } \\
\text { column }\end{array}$ & Observation & Results \\
\hline Water & Ethyl acetate & $\mathrm{N} / \mathrm{A}$ & $\begin{array}{l}\text { SPE Bond } \\
\text { Elut } \mathrm{NH}_{2} \\
\text { column }\end{array}$ & $\begin{array}{l}\text { Poor recovery rate for } \\
\text { esterified forms of } 3- \\
\text { MCPD }\end{array}$ & Rejected \\
\hline Water & Diethyl ether & $\mathrm{N} / \mathrm{A}$ & $\mathrm{N} / \mathrm{A}$ & $\begin{array}{l}\text { Poor recovery rate for } \\
\text { esterified forms of 2- } \\
\text { MCPD and 3-MCPD }\end{array}$ & Rejected \\
\hline Water & $\begin{array}{c}\text { Ethanol/n- } \\
\text { hexane/diethyl } \\
\text { ether }(1 / 1 / 1, v / v / v)\end{array}$ & $\begin{array}{l}\text { Evaporation of } \\
\text { extraction solvent, } \\
\text { then re-dissolving the } \\
\text { residue in n-hexane }\end{array}$ & $\mathrm{N} / \mathrm{A}$ & $\begin{array}{l}\text { Poor recovery rates } \\
\text { for esterified forms of } \\
\text { both 2-MCPD and 3- } \\
\text { MCPD }\end{array}$ & Rejected \\
\hline Water & $\begin{array}{c}\text { Ethanol/n- } \\
\text { hexane/ diethyl } \\
\text { ether }(1 / 1 / 1, v / v / v)\end{array}$ & $\begin{array}{l}\text { Evaporation of } \\
\text { extraction solvent, } \\
\text { then redissolving the } \\
\text { residue in } n \text { - hexane }\end{array}$ & $\begin{array}{l}\text { SPE Bond } \\
\text { Elut SI } \\
\text { column }\end{array}$ & $\begin{array}{l}\text { Recovery 2-MCPD } \\
\text { and 3-MCPD esters } \\
\text { were ameliorated but } \\
\text { not as good as those } \\
\text { obtained using SPE- } \\
\mathrm{NH}_{2} \text { column }\end{array}$ & Rejected \\
\hline Water & $\begin{array}{c}\text { Ethanol/n- } \\
\text { hexane/diethyl } \\
\text { ether }(1 / 1 / 1, v / v / v)\end{array}$ & $\begin{array}{l}\text { Evaporation of } \\
\text { extraction solvent, } \\
\text { then re-dissolving the } \\
\text { residue in n- hexane }\end{array}$ & $\begin{array}{l}\text { SPE Bond } \\
\text { Elut } \mathrm{NH}_{2} \\
\text { column }\end{array}$ & $\begin{array}{l}\text { Good recovery rates } \\
\text { for esterified forms of } \\
\text { both 2-MCPD and 3- } \\
\text { MCPD }\end{array}$ & $\begin{array}{l}\text { Selected } \\
\text { for final } \\
\text { method }\end{array}$ \\
\hline
\end{tabular}




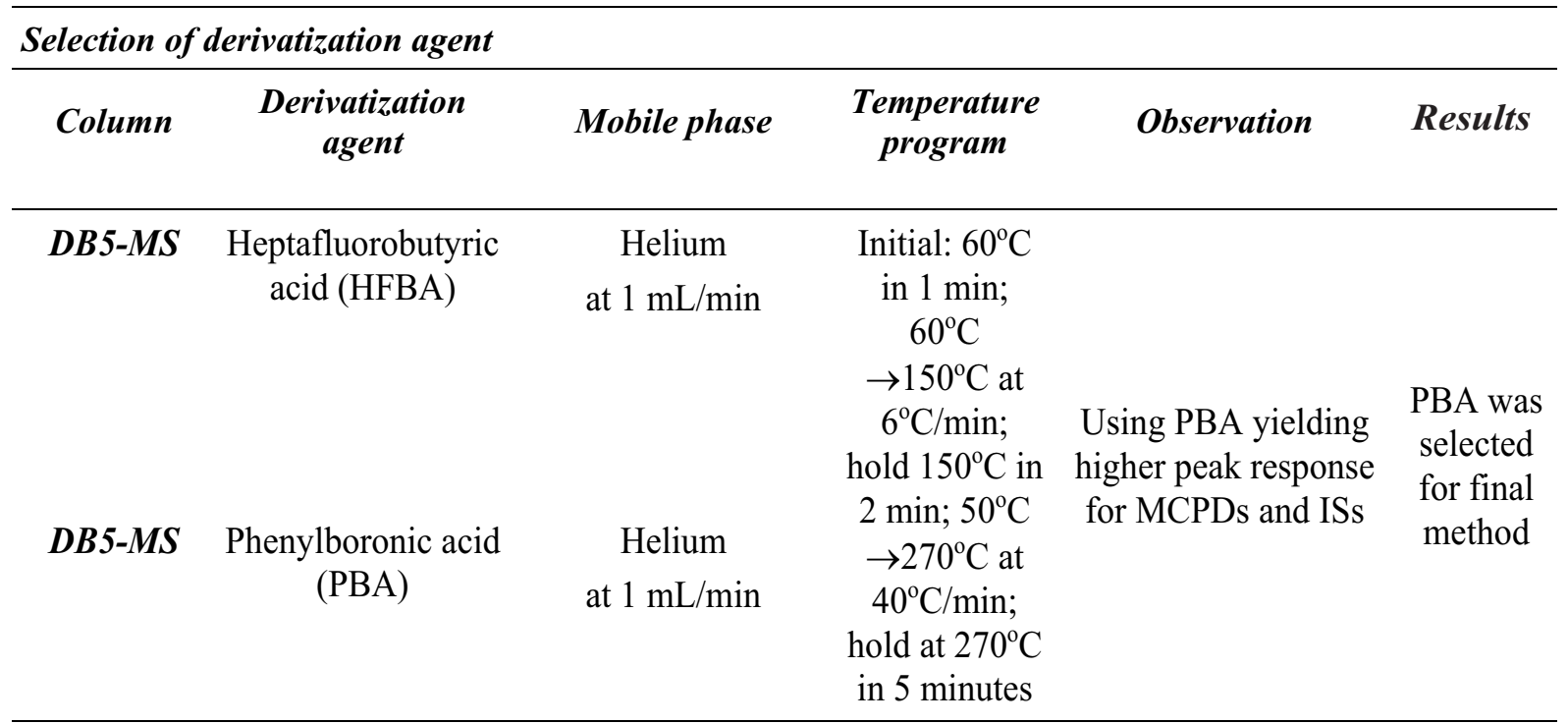
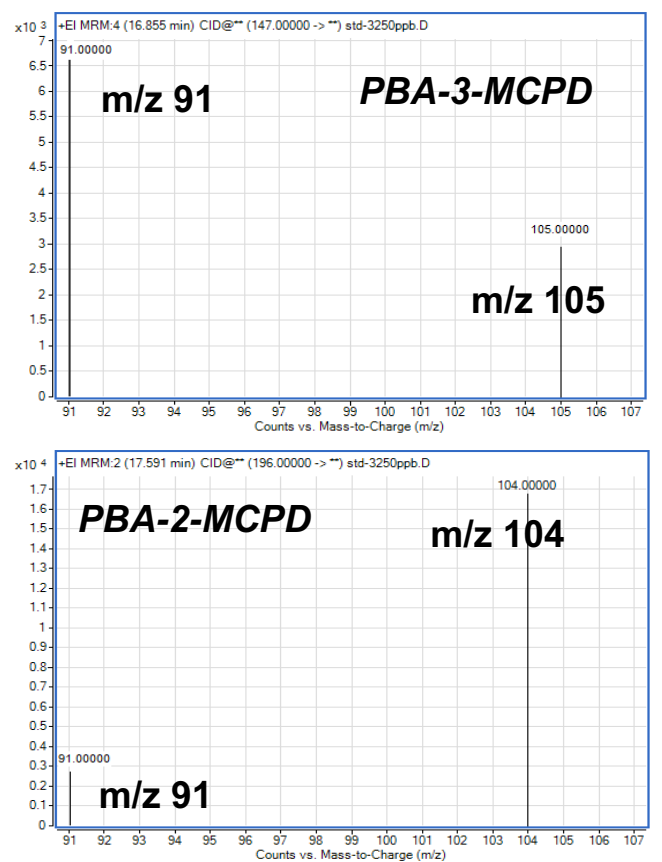

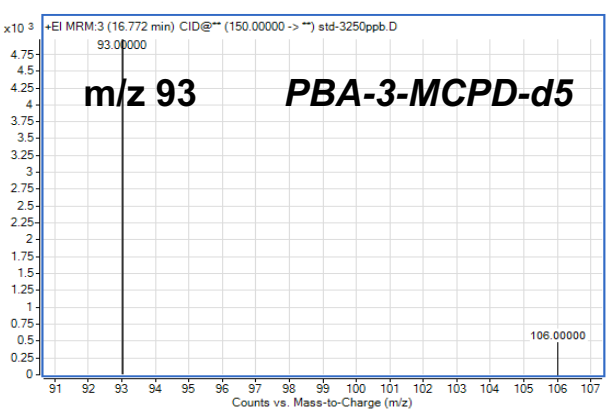

$\mathrm{m} / \mathrm{z} 106$

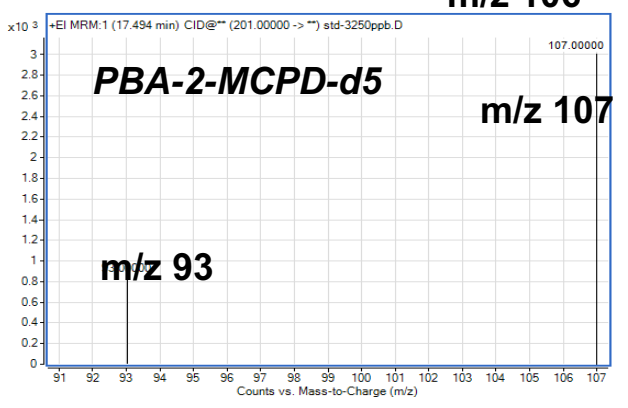

Figure 1. Formation of product ions of PBA-3-MCPD (from ion $\mathrm{m} / \mathrm{z} 147$ ), $P B A-2-M C P D$ (from ion $\mathrm{m} / \mathrm{z}$ 196), $P B A-3-M C P D-d 5$ (from ion $\mathrm{m} / \mathrm{z} 150$ ), and $P B A-2-M C P D-d 5$ (from ion $\mathrm{m} / \mathrm{z} 201$ )

After the optimization, the chromatographic conditions as mentioned in 2.4 were used for method validation.

\subsection{Method validation}

\subsubsection{Specificity}

For specificity evaluation, blank sample, spike sample with PP-MCPDs, spike sample with MCPD and standard were analyzed. Some chromatograms are presented in Figure 2. 

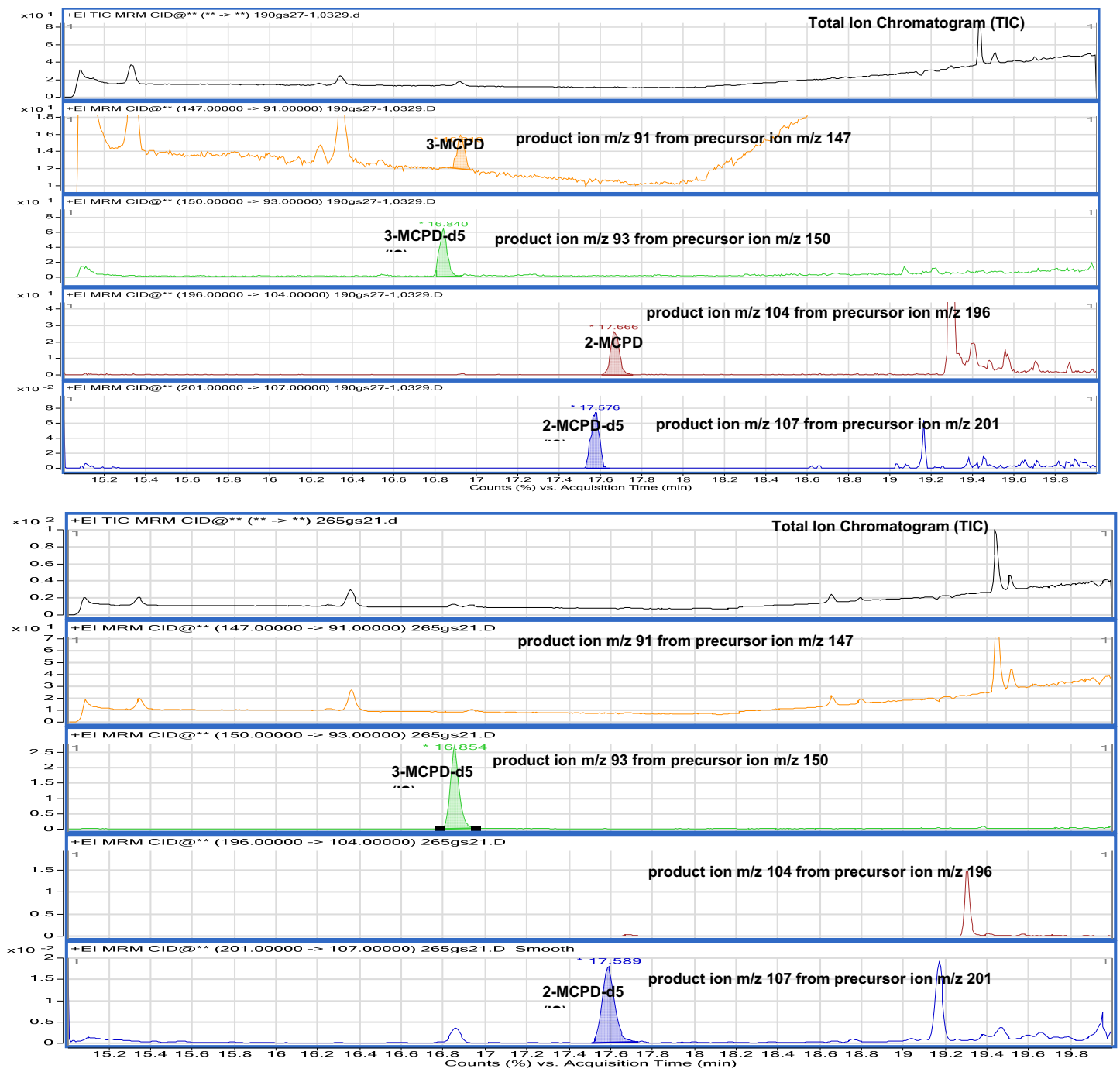

Figure 2. Some typical chromatograms (1 - 5: chromatograms of 2-MCPD and 3-MCPD esters spiked sample; 6 - 10: chromatograms of a blank sample)

In selected chromatographic conditions, 3-MCPD and 2-MCPD were well separated one from other. The two ISs, 3-MCPD-d5 and 2-MCPD-d5, were well separated from each other and eluted closely with their corresponding isotope (Figure 2). Chromatogram of sample spiked with PP-3-MCPD, PP-2-MCPD, PP-3-MCPD-d5 and PP-2-MCPD-d5, showed peaks corresponding to 3-MCPD, 2-MCPD and 3-MCPD-d5 and 2-MCPD-d5, whereas chromatogram of sample spiked with free 3-MCPD, 2-MCPD, 3-MCPD-d5 and 2-MCPD-d5 showed no peak of these compounds. The use of SPE with $\mathrm{NH}_{2}$ cartridge retained MCPDs in the ester forms but removed the free forms. This result indicated that the GC-MS/MS developed was specific for determination of esterified forms of 3-MCPD and 2-MCPD in infant formula, and the presence of free 3-MCPD and 2-MCPD would not interfere with the analysis results.

\subsubsection{Calibration curve}

The ratio between peak areas of quantitative product ions of 3-MCPD and 2-MCPD and those of quantitative product ions of IS obtained from the GC-MS/MS analysis was plotted against corresponding ratio between concentrations of MCPDs and corresponding ISs to obtain 
the calibration graph. The results of linearity study (Figure 3) gave linear relationship over the concentration range of $100-2.500 \mathrm{ng} / \mathrm{mL}$ (or 25 to $625 \mu \mathrm{g} / \mathrm{kg}$ in matrices) for 3-MCPD and 2-MCPD. From the regression analysis, the linear equation was obtained: $y=0.526 x+0.140$ for 3-MCPD and $\mathrm{y}=0.865 \mathrm{x}+0.128$ for $2-\mathrm{MCPD}$, and the coefficient of determination R-square was 0.999 for both analytes, indicating a linear relationship between the concentration of analyte and area under the peak.

A

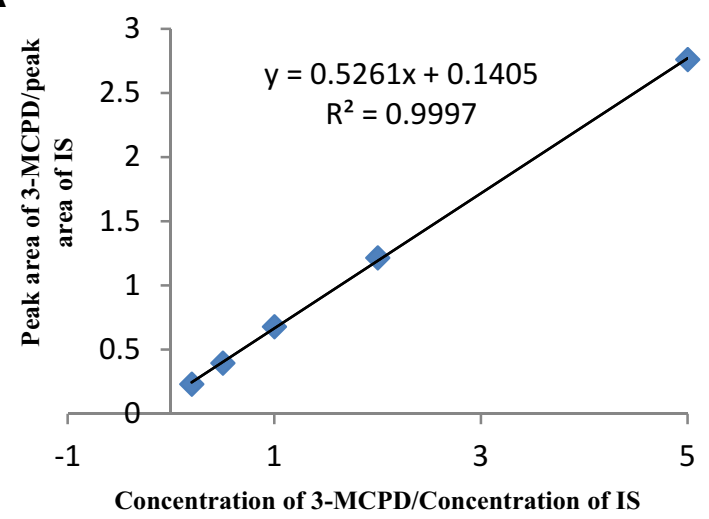

B

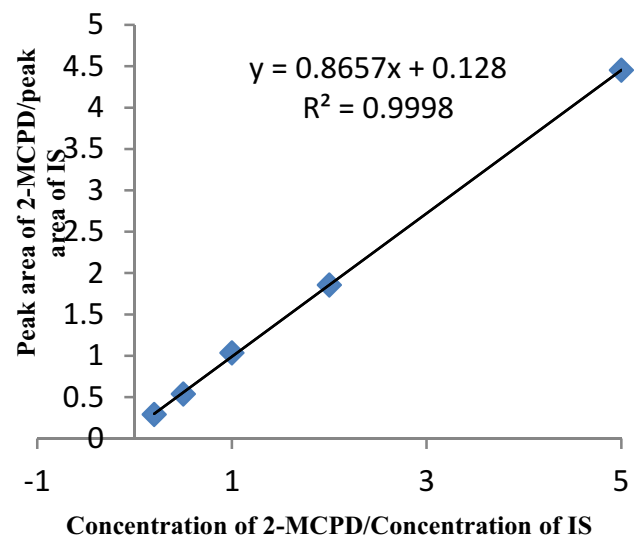

Figure 3. Calibration curves of 3-MCPD (A) and 2-MCPD (B)

\subsubsection{Limit of detection (LOD) and limit of quantification (LOQ)}

For 3-MCPD and 2-MCPD, the concentration of injected solution at LOD was 28.0 $\mathrm{ng} / \mathrm{mL}$, equivalent to $7.0 \mathrm{mg} / \mathrm{kg}$ of $3-\mathrm{MCPD}$ and 2-MCPD, respectively, under esterified form(s) in infant formula; the concentration of injected solution at LOQ were $100.0 \mathrm{ng} / \mathrm{mL}$, equivalent to $25 \mathrm{mg} / \mathrm{kg}$ of 3-MCPD and 2-MCPD, respectively, under esterified form(s) in infant formula. The LOQ for 3-MCPD and 2-MCPD of the method met the requirements of AOAC International [14].

\subsubsection{Accuracy}

In this study, the results of recovery studies gave recovery rate falling within the recovery range recommended by AOAC International at all three levels for all the two analytes, and RSD values at each level for each analyte varied within the range recommended by AOAC International [14], as shown in Table 3.

Table 3. Summary results of recovery, repeatability $(n=6)$ and intermediate precision $(n=9)$ of 2-MCPD and 3-MCPD esters

\begin{tabular}{ccccccc}
\hline \multirow{2}{*}{$\begin{array}{c}\text { Level } \\
(\boldsymbol{\mu g} / \mathbf{k g})\end{array}$} & $\begin{array}{c}\text { Repeatability } \\
\text { RSD (\%) }\end{array}$ & $\begin{array}{c}\text { Intermediate } \\
\text { Precision } \\
\text { RSD (\%) }\end{array}$ & $\begin{array}{c}\text { Recovery } \\
(\%)\end{array}$ & $\begin{array}{c}\text { Repeatability } \\
\text { RSD (\%) }\end{array}$ & $\begin{array}{c}\text { Intermediate } \\
\text { Precision } \\
\text { RSD (\%) }\end{array}$ & $\begin{array}{c}\text { Recovery } \\
(\%)\end{array}$ \\
\hline 25 & 4.5 & 4.2 & 90.7 & 3.5 & 5.0 & 87.9 \\
125 & 1.9 & 2.2 & 103.9 & 1.6 & 1.7 & 99.9 \\
500 & 1.9 & 2.0 & 89.9 & 1.8 & 2.1 & 94.1 \\
$\begin{array}{c}\text { Requirement } \\
{[14]}\end{array}$ & $\leq 22$ & - & $70-125$ & $\leq 22$ & - & $70-125$ \\
\hline
\end{tabular}




\subsubsection{Precision}

As shown in Table 3, the repeatability and intermediate precision all met the requirements of AOAC International [14]. Therefore, the results of method precision showed that the method is precise within the acceptable limits.

\subsection{Application}

The GC-MS/MS method developed in this study has been applied to detect esterified 3-MCPD and 2-MCPD in 72 infant formula samples collected randomly on the markets and commercial centres at 2 cities (Ha Noi and Hai Phong) and 2 provinces (Thai Nguyen and Thua Thien-Hue) in Vietnam. The analysis of free 3-MCPD and 2-MCPD showed that no sample contain detectable levels of 3-MCPD or 2-MCPD under free form. In contrast, 3-MCPD under esterified forms were detected in 28 samples $(38.9 \%)$ at total level equivalent to 3-MCPD from $35-478$ $\mathrm{mg} / \mathrm{kg}$, and 2-MCPD under esterified forms were detected in 25 samples (34.7\%) at total level equivalent to 2-MCPD from $28-147 \mathrm{mg} / \mathrm{kg}$. Among the contaminated samples, 22 samples $(30.5 \%)$ contained both 3-MCPD and 2-MCPD under esterified forms. These findings were corroborated with results of other published work, which revealed existence of MCPDs in infant formula mainly under esterified forms [2].

\section{CONCLUSION}

In this study, a sensitive, accurate and precise GC-MS/MS method has been developed for determination of 3-MCPD and 2-MCPD under ester forms in infant formula. The method was validated according to the AOAC International guideline and proved suitable for the intended application, able to provide accurate and precise quantitative results under minor variation of chromatographic conditions. Further studies on the food consumption may be needed for health risk assessment of these compounds.

\section{ACKNOWLEDGEMENT}

This original research was funded by the National Institute for Food Control in 2018, Vietnam.

\section{REFERENCES}

[1] Z. Zelinková, M. Doležal and J. Velíšek, “Occurrence of 3-chloropropane-1, 2-diol fatty acid esters in infant and baby foods", European Food Research and Technology, vol. 228, no. 4, pp. 571-578, 2009.

[2] J. K. Beekman, K. Grassi and S. MacMahon, "Updated occurrence of 3-monochloropropane1, 2- diol esters (3-MCPD) and glycidyl esters in infant formulas purchased in the United States between 2017 and 2019", Food Additives \& Contaminants: Part A, vol. 37, no. 3, pp. 374-390, 2020.

[3] C. G. Hamlet, P. A. Sadd, C. Crews, J. Velíšek and D. E. Baxter, "Occurrence of 3-chloropropane-1, 2-diol (3-MCPD) and related compounds in foods: a review", Food Additives \& Contaminants, vol. 19, no. 7, pp. 619-631, 2002.

[4] Z. Zelinková, B. Svejkovská, J. Velíšek, and M. Doležal, "Fatty acid esters of 3-chloropropane-1, 2-diol in edible oils", Food Additives and Contaminants, vol. 23, no. 12, pp. 1290-1298, 2006.

[5] W. Seefelder, G. Scholz and B. Schilter, "Structural diversity of dietary fatty esters of chloro- 
propanols and related substances", European Journal of Lipid Science and Technology, vol. 113, no. 3, pp. 319-322, 2011.

[6] J. K. Lee, J. A. Byun, S. H. Park, H. S. Kim, J. H. Park, J. H. Eom and H. Y. Oh, “Evaluation of the potential immunotoxicity of 3-monochloro-1, 2-propanediol in Balb/c mice: I. Effect on antibody forming cell, mitogen-stimulated lymphocyte proliferation, splenic subset, and natural killer cell activity", Toxicology, vol. 204, no. 1, pp. 1-11, 2004.

[7] B. S. Lynch, D. W. Bryant, G. J. Hook, E. R. Nestmann, and I. C. Munro, "Carcinogenicity of monochloro-1, 2-propanediol ( $\alpha$-chlorohydrin, 3-MCPD)", International Journal of Toxicology, vol. 17, no. 1, pp. 47-76, 1998.

[8] S. J. Kwack et al., "Mechanism of antifertility in male rats treated with 3-monochloro-1, 2-propanediol (3-MCPD)", Journal of Toxicology and Environmental Health, Part A, vol. 67, no. 23-24, pp. 2001-2004, 2004.

[9] W. Seefelder, N. Varga, A. Studer, G. Williamson, F. P. Scanlan, and R. H. Stadler, "Esters of 3-chloro-1, 2-propanediol (3-MCPD) in vegetable oils: significance in the formation of 3-MCPD”, Food Additives and Contaminants, vol. 25, no. 4, pp. 391-400, 2008.

[10] E. P. on C. in the F. Chain (CONTAM), "Risks for human health related to the presence of 3-and 2-monochloropropanediol (MCPD), and their fatty acid esters, and glycidyl fatty acid esters in food", Efsa Journal, vol. 14, no. 5, p. e04426, 2016.

[11] E. Commission (EC), Opinion of the Scientific Committee on Food on 3-Monochloropropane-1, 2-diol (3-MCPD). EC Brussel, Belgium, 2001.

[12] T. D. Haines, K. J. Adlaf, R. M. Pierceall, I. Lee, P. Venkitasubramanian, and M. W. Collison, "Direct determination of MCPD fatty acid esters and glycidyl fatty acid esters in vegetable oils by LC-TOFMS", Journal of the American Oil Chemists' Society, vol. 88, no. 1, pp. 1-14, 2011.

[13] V. G. Samaras, A. Giri, Z. Zelinkova, L. Karasek, G. Buttinger, and T. Wenzl, "Analytical method for the trace determination of esterified 3-and 2-monochloropropanediol and glycidyl fatty acid esters in various food matrices", Journal of Chromatography A, vol. 1466, pp. 136-147, 2016.

[14] J. Kuhlmann et al., "Standard method performance requirements (SMPRs ${ }^{\circledR}$ ) 2017.017: Determination of 2-and 3-MCPD, 2-and 3-MCPD esters, and glycidyl esters in infant and adult/pediatric nutritional formula", Journal of AOAC International, vol. 101, no. 1, pp. 324326, 2018.

[15] M. Dubois, A.-M. Empl, G. Jaudzems, Q. Basle, and E. Konings, "Determination of 2-and 3-MCPD as well as 2-and 3-MCPD esters and glycidyl esters (GE) in infant and adult/pediatric nutritional formula by gas chromatography coupled to mass spectrometry method, First Action 2018.03”, Journal of AOAC International, vol. 102, no. 3, pp. 903-914, 2019. 


\section{Xác định đồng thời các dạng ester của 3-MCPD và 2-MCPD trong sữa công thức bằng GC-MS/MS}

\section{Lê Đình Chi', Nguyễn Như Thượng ${ }^{1,2}$, Vũ Ngọc Tú ${ }^{2}$ Lê Thị Hồng Hảo ${ }^{2}$, Trần Cao Sơn²}

${ }^{1}$ Truoòng Đại học Dược Hà Nội ${ }^{2}$ Viện Kiểm nghiệm an toàn vệ sinh thực phẩm Quốc gia

\section{Tóm tắt}

Nghiên cứu đã phát triển và thẩm định phương pháp xác định đồng thời các dạng ester của $3-\mathrm{MCPD}$ và $2-\mathrm{MCPD}$ trong sữa công thức bằng GC-MS/MS. Các ester của MCPD được chiết từ mẫu sữa công thức bằng hỗn hợp ethanol/n-hexane/diethyl ether $(1 / 1 / 1, \mathrm{v} / \mathrm{v} / \mathrm{v})$, sau đó được xử lý với acid sulfuric để giải phóng dạng tự do. Các chất $3-\mathrm{MCPD}$ và $2-\mathrm{MCPD}$ dạng tự do và nội chuẩn đồng vị $3-\mathrm{MCPD}-\mathrm{d} 5$ and $2-\mathrm{MCPD}-\mathrm{d} 5$ được dẫn xuất với acid phenylboronic và sau đó dẫn xuất được phân tích bằng GC-MS/MS ở chế độ MRM. Cột tách được sử dụng là cột mao quản DB-5MS, khí mang là Heli ở tốc độ $1 \mathrm{~mL} /$ phút. Chế độ MRM đã được sử dụng để lựa chọn 1 ion mẹ và 2 ion con cho mỗi chất phân tích. Kết quả thẩm định cho thấy phương pháp đáp ứng các yêu cầu theo AOAC SMPR. Phương pháp đã được ứng dụng để xác định các ester của 3-MCPD và 2-MCPD trong các mẫu sữa công thức lấy ở một số tỉnh, thành phố của Việt Nam. Có 38,9\% số mẫu phát hiện 3-MCPD ester và 34,7\% số mẫu phát hiện 2-MCPD ester.

Tù̀ khóa: esters, 3-MCPD, 2-MCPD, GC-MS/MS, sĩua công thúc. 